\title{
Investigating career guidance needs of middle school students
}

\author{
Süleyman Balc1 ${ }^{*}$ \\ ${ }^{1}$ Kırıkkale University, Education Faculty, Guidance and Counseling Department, Yahşihan, \\ Kirıkkale, 71450
}

\begin{abstract}
Purpose of this study is to analyze career guidance needs of middle school students. This study has been carried out in 2017-2018 academic year. Participants of this study are year-seven students of middle schools $(n=241)$. In order to determine the sample, purposeful sampling technique were used. In the study, it was used Guidance Needs Determining Form, which is three-likert-type scale and were developed for primary education students. This scale has three sub-scales as personal/social guidance needs, career guidance needs and educational guidance needs. Sub-scale of career guidance needs were used to collect necessary data. Subsequently, frequencies and percentages concerning data of sub-scale items of career guidance needs were calculated. Moreover, findings related with career guidance needs of middle school students were given as in the table. Results have shown that career guidance needs of middle school students is meaningfully high in terms of some items.
\end{abstract}

\section{Introduction}

People need to work for a variety of reasons, especially to earn a living, honor and contribute to their families and communities, achieve self-growth, establish a public identity, and structure their lives. Moreover, there are several more reasons for working such as social and psychological needs like friendship, intimacy, self-esteem and personal growth for need of fulfillment. Because work can enable people to meet basic survival needs and provide the context for fulfilling people's needs for security, social belonging and intimacy by enhancing the material comfort of one's family as well as personal esteem by providing a sense of personal worth and accomplishment. In addition, Super, Savickas \& Super claim that work provide personal identity as an expression of self-image and a selfconcept. Situations and roles related with work has great importance in people's lives by considering the reasons of why people work [1] .

\footnotetext{
* Corresponding author: meb.suleyman@gmail.com
} 


\subsection{Career development and developmental career theories}

Career development is defined as a process that encompasses much of the life span from beginning of childhood to adulthood. In other words, it begins in childhood and includes the formal and informal experiences that give rise to talents, interests, values, and knowledge of the world of work, continues into adulthood via the progression of one's career behavior such as entry into and adjustment to work throughout life span [2]. According to Gysbers career development is self-development over the lifetime through the integration of the roles, settings, and events in a person's life [3]. Several factors such as people's gender, ethnic origin, spirituality, race, sexual orientation, and socioeconomic status may influence one's career development by shaping the life roles, lifesettings and life events of people. Career development also pertains to the interventions used by practitioners to facilitate age and situation appropriate career behaviors across one's lifetime [4].

Career theories provide systems for explaining which factors operate together to determine occupational choice and development over the life periods such as preparation for work with education and training, work entry, adjustment to work and disengagement from work. Developmental career theories explain how the work role relates to other life roles such as parent and leisurite, how contextual factors such as socioeconomic status affect career trajectories and how people partly construct their own career and life stories and experiences. In addition, developmental career theories state the predictable tasks and challenges that accompany career development such as learning about oneself, exploring the world of work, developing a vocational identity, narrowing down career options from a broad range of career alternatives and establishing and maintaining one's career.

Developmental career theory of Super proposes that career choice and development includes a lifelong and developmental process that begins in childhood and proceeds continuously over the life time. Each life period presents particular problems to solve, and these problems may surface and resurface in predictable and unpredictable ways at various times in life. By taking attention to the developmental nature of careers, counselors can help clients understand and deal with developmental tasks to promote effective career planning, career exploration, career decision making at all life periods for designing their careers and navigating successfully through anticipated transitions. In addition, Super's theory contributes counselors for assisting students to arrange their work and other life roles into a livable and satisfying pattern. According to Super, major roles in life constitute the typical life structure in chronological order of child, student, leisurite, citizen, worker, spouse, homemaker, parent, and annuitant [5]. Among these roles, the worker role typically represents a core role, given the cultural, social, and personal imperative to work.

In the developmental theory of occupational choice, Ginzberg, Ginsburg, Axelrad, and Herma argued that children's first career awareness is developed as a fantasy [6]. Children at about age 11 begin to become aware of themselves in relation to the world of work and their interests and choices become more crystallized at about age 18. These life periods are called relatively fantasy stage, tentative stage and realistic stage in this theory.

Another developmental theory is Developmental Theory of Circumscription and Compromise developed by Gottfredson [7]. This theory supposes that circumscription and compromise processes exist for deciding apporiate career in middle and later adolescence. The process of circumscription involves continually narrowing of occupations that person will consider. Compromise process includes eliminating the most preferred career options for less compatible careers. By this way, children and adolescents can reach the fulfillment of their internal unique selves by choosing occupations that they perceive to be more socially acceptable. This process begins in early childhood by identifying segments of the occupational world as unattainable. Moreover, this process continues throughout middle 
and later adolescence. During this life stage adolescents make vocational preparation decisions that is more likely affect their ability to enter into more prestigious careers [7] [8].

According to Gottfredson's theory, children are influenced by their understanding of prescribed gender and prestige roles within social environment. As a result of this influence, children may have consideration about their own interests, values, competencies, and intelligence. This theory supposes that from ages 3 to 5 children become oriented to size and power. Moreover, children (ages 6 to 8 ) become aware of socially determined gender roles. Between 9 and 13, they become oriented to these roles which social class and abilities play in their career aspirations and choices in future [8].

According to Gottfredson, socialization plays important roles in children's developing career awareness [7]. Career choices are eventually made through a process of orientation to vocational choice, gathering information and planning, and developing one's selfconcept. Assisting children in this process may be necessary to enable them become aware of career possibilities by providing appropriate and timely information [9].

\subsection{Career guidance in schools}

Career guidance contains the career-orienting activities which are generally provided by school counselors and teachers in order to help students to become aware of possible career alternatives with a variety of services such as guidance, advising, education, placement, coaching, and mentoring in educational settings [10]. Many countries recognise the importance of career guidance programs in terms of enhancing the lives of their citizens and improving their economy [11]. Several type of guidance services are delivered according to the country or location of the service provider [12]. In some countries, such as the United States and Turkey, career guidance is often delivered as a part of the school counselors' responsibilities [13]. Career guidance services were provided by means of several formats, such as individually, group-based, face-to-face, or at a distance including help-lines and web-based services.

Guichard emphisized that career guidance should be lifelong, comprehensive and accessible in a way that is suitable for people in terms of their economic, social, cultural, educational, and personal situation [14]. Likewise, according to Killeen and White [15] career guidance is needed to be lifelong, accessible, and meaningful for all individuals. This can be possible with the collaboration of trainers, practitioners and teachers, school counselors and other personnels to guarantee the integration and evaluation career guidance services and the effectiveness of career guidance [16].

It was determined that career guidance interventions which involve a career counsellor were significantly more effective than those interventions that were without career counselor. Particularly, when computer system and career counseling were used together it may be more effective than allowing individuals to just use a computerised guidance system [17].

As for data collection regarding evaluation of career guidance interventions, Benkofske and Heppner stressed that data collection can be rather straightforward with proper planning and preparation [18]. Before gathering data it is needed what information is necessary and the most appropriate methods for collecting that information. Otherwise, the entire evaluative process may produce negative consequences for the career guidance program suh as insufficient data to support ongoing funding. Prior to actual process, piloting the data collection process may be suitable option to identify possible problems, such as participants' misunderstanding the instructions or survey questions or difficulties in retrieving archival or institutional data concerning graduation rate and employment record of participants. 


\subsection{Career guidance needs of children and adolescents}

School counselors provide career guidance for students in order to help them become aware of possible career alternatives with a variety of services such as guidance, advising, education, placement, coaching, and mentoring in educational settings [19]. Moreover, While practising these career guidance activities, school counselors assist these children and adolescents explore working environment and give information about working conditions and materials used during working [8]. Need for career guidance and counseling in elementary and secondary schools has been getting greater [4]. As a result of this necessity, career guidance and counselling activities is increasingly delivered in elementary and secondary schools in some countries such as Turkey [12].

It is possible to promote career awareness among elementary and secondary children and adolescents by enabling them to visit work places and observing the types and process of jobs that workers do in work places [20]. In addition to visiting work places, mentoring can enable children and adolescents to broaden their awareness about job tasks, attitudes, and supports needed to work successfully in any occupation. By this way, children who live in rural areas with fewer opportunities may gain early awareness concerning certain specialized careers and can prepare themselves in middle school and high school for entry into high school and university department regarding specialized careers [21]. Moreover, computerized career guidance and information systems have been developed to aid the guidance function.

Children and adolescents need to learn sets of skills and develop the types of motivational styles and approaches that will assist them in their efforts to establish satisfying life structures across their lifetime [1]. School counselors help children and adolescents understand their abilities, interests, values, and personality styles; the specifics of current labor market information; and how to make better and more satisfying career decisions in order to establish appropriate career development and manage for the significant challenges they face creatively and proactively [22]. Because children and adolescents experience difficulties and special challenges such as gender related circumscription of vocational aspirations, career decision-making readiness, and school-toschool or school-to-work transitioning during their career development. In addition, Career guidance assistance provided by school counselors for students help them develop career awareness, support career development and develop satisfying, productive, and fulfilling career choices in future.

What knowledge should students acquire, what skills should they develop, and what attitudes should they form as a result of participating in the activities of career guidance and counselling? These are important questions because they presuppose that there are learning outcomes for career guidance and counselling. Replying these questions is important because it is necessary to determine contents of career guidance to meet the needs of students [2]. For this reason, this study is related with career guidance needs of year-seven middle school students. Therefore, purpose of this study is to analyze career guidance needs of year-seven students of middle schools.

\section{Method}

\subsection{Sample}

In order to determine the sample of this study, purposeful sampling technique were used. This study has been carried out in 2017-2018 academic year. Students from nine different 
middle schools in a urban area in a small province in the middle region of Turkey participated in the study $(\mathrm{N}=241)$. All students were in the seventh grade and their ages ranged from 12 to 13 years. Almost half of participants were girls $(\mathrm{n}=120),(49,5 \%)$ attending the seventh grade of these schools.

\subsection{Data collection and analysis}

In the study, Guidance Needs Determining Form was used. This instrument is a three-likerttype scale and were developed by Erkan for primary education students [23]. This scale contains 26 items concerning guidance needs of primary education students and have three sub-scales. These sub-scales are personal/social guidance needs, career guidance needs and educational guidance needs. Items regarding sub-scale of career guidance needs were used to collect necessary data related with career guidance needs of seventh grade students. Participants were asked to rate all items used in this investigation on a 3-point Likert scale $(1=$ no, $2=$ undecided, $3=$ yes $)$. Subsequently, frequencies and percentages concerning data of sub-scale items of career guidance needs were calculated. Before conducting data gathering instrument, it has been taken official permission by researcher from district educational administration for collecting data with this scale in schools.

\section{Results}

After collecting necessary data concerning career guidance needs stated by year seven students $(\mathrm{n}=241)$ of middle schools by conducting Guidance Needs Determining Form, the frequency and percentage (\%) values of each item were calculated. These values are given in the table 1.

Table 1. Career Guidance Needs of Middle School Students $(n=241)$

\begin{tabular}{|c|c|c|c|c|c|c|}
\hline Items for career guidance needs & \multicolumn{6}{|c|}{ frequency } \\
\hline & Yes & $\%$ & Undecided & $\%$ & No & $\%$ \\
\hline 11- I need to learn jobs which I will be succesful mostly & 119 & 49 & 59 & 25 & 63 & 26 \\
\hline 12- I need to learn features of several vocations & 109 & 45 & 52 & 22 & 80 & 33 \\
\hline $\begin{array}{l}\text { 13- I need to learn how what I learn in school will help me for my } \\
\text { vocation in future }\end{array}$ & 129 & 54 & 45 & 19 & 67 & 28 \\
\hline 14- I need to learn about necessary education for several vocations & 121 & 50 & 55 & 23 & 65 & 27 \\
\hline $\begin{array}{l}15 \text { - I need to learn relations of my interest and aptitudes with my } \\
\text { vocation in future }\end{array}$ & 139 & 58 & 46 & 19 & 56 & 23 \\
\hline 16- I need to learn which activities people do in various vocations & 86 & 36 & 65 & 27 & 90 & 37 \\
\hline 17- I need to learn which activities will make me happy & 121 & 50 & 33 & 14 & 87 & 36 \\
\hline
\end{tabular}

As seen in the table, career guidance need with highest ratio is item 15 with $58 \%$ 'yes'; Item with second highest ratio is item 13 with $54 \%$ 'yes'; next item with highest ratio is item 14 and 17 with $50 \%$ 'yes'; than other items coming is item 11 and 12 with 49 and 45 $\%$ 'yes'; item with lowest ratio is item 16 with $36 \%$ 'yes'. 


\section{Conclusion}

Purpose of this study is to analyze career guidance needs of year-seven students of middle schools. According to the finding of data analysis, career guidance needs of year-seven students is meaningfully high in terms of item 15 and 13 with 58 and $54 \%$ 'yes'. Results related with career guidance needs of year-seven students have shown that year-seven students need career guidance so high that it is necessary to practice planned and comprehensive career counseling regularly and periodically. In addition, this result indicates that these students need career guidance activities for their optimum career development and suitable working options in future.

\section{References}

1. Super D. E., Savickas, M. L., \& Super, C. M. The life-span, life-space approach to careers. In D. Brown \& L. Brooks (Eds.), Career choice and development: Applying contemporary theories to practice (3rd ed., pp. 121-178). San Francisco, CA: JosseyBass. (1996)

2. Gysbers, N. C. Career guidance and counselling In primary and secondary Educational settings. In Athanasou, J.A. \& Van Esbroeck, R. (Eds.). International Handbook of Career Guidance ( pp. 249-264). Springer Science \& Business Media B.V. (2008)

3. Gysbers, N. C. Implementing a whole school approach to guidance through a comprehensive guidance system. As. J. Coun., 7, 5-17. (2000)

4. Herr E. L. Social Contexts for Career Guidance Throughout the World. In Athanasou, J.A. \& Van Esbroeck, R. (Eds.) International Handbook of Career Guidance (pp. 4569). Springer Science \& Business Media B.V. (2008)

5. Super, D. E. A life-span, life-space approach to career development. In D. Brown \& L. Brooks (Eds.), Career choice and development: Applying contemporary theories to practice (2nd ed., pp. 197-261). San Francisco, CA: Jossey-Bass (1990)

6. Ginzberg, E., Ginsburg, S., Axelrad, S., \& Herma, J., Occupational choice: An approach to a general theory. New York, NY: Columbia University Press. . (1951)

7. Gottfredson, L. S. Applying Gottfredson's theory of circumscription and compromise in career guidance and counseling. In S. D. Brown \& R. T. Lent (Eds.), Career development and counseling: Putting theory and research to work (pp. 71-100). Hoboken, NJ: Wiley. (2005.

8. Turner, S. L. \& Lapan, R.T. Development, and school success in children and adolescents. In Brown, S. D.\& Lent, R. W. (Eds) Career development and counseling : putting theory and research to work (2nd ed.). Hoboken, New Jersey, USA: John Wiley \& Sons, Inc. (2013)

9. Patton, W., \& McMahon, M. Theoretical and practical perspectives in Australia. I. J. Ed. Voc. Gui., 2, 39-49. (2002)

10. Savickas, M. L. The theory and practice of career construction. In S. Brown \& R. Lent (Eds.), Career development and counseling: Putting theory and research to work (pp. 42-70). Hoboken, NJ: Wiley. (2005)

11. Hartung, P. J. Internationalizing career counseling: Emptying our cups and learning from each other. Car. Dev. Qua, 54, 12-16. (2005)

12. Watts, A. G., \& Sultana, R. G. Career guidance in 37 countries: Contrast and common themes. I. J. Ed Voc. Gui.e, 4, 105-122. (2004) 
13. Whiston, S. C., Eder, K., Tai, W. L., \& Rahardja, D. Research supporting schoo lcounseling: Comprehensive findings. Paper presented at the annual meeting of the American School Counselor Association, Orlando, FL. (2005)

14. Guichard, J. Career counselling for human development: An international perspective. Car. Dev. Qua., 51, 306-321. (2003)

15. Killeen, J., \& White, M. The impact of careers guidance on adult employed people. DfEE Research Report, Sheffield, UK: Department for Education and Employment. (2000)

16. Balc1, S. Perceptions of teacher candidates concerning ethically suitable behaviours for teaching profession. SHS Web of C. 31, 01020. (2016)

17. Whiston, S.C. \& Buck I.M. Evaluation of career guidance programs. In Athanasou, J.A. \& Van Esbroeck, R. (Eds.) International Handbook of Career Guidance (pp. 677-694). Springer Science \& Business Media B.V. (2008)

18. Benkofske, M., \& Heppner, C. C. Program evaluation. In P. P. Heppner, D. M. Kivlighan, \& B. E. Wampold (Eds.), Research design in counseling (pp. 488-513). Belmont, CA: Wadsworth. (1999)

19. Savickas, M. L. Career construction: A developmental theory of vocational behavior. In D. Brown (Ed.), Career choice and development (4th ed., pp. 149-205). San Francisco, CA: Jossey-Bass. (2002)

20. Balc1, S. Analysis of metaphoric perceptions stated by candidate school counselors regarding contribution of the career guidance for students. PESA Int. J. S. S., 3:4, 193202. (2017)

21. Balc1, S. Investigating metaphoric perceptions stated by candidate science teachers regarding contribution of the guidance services at school for students (fen bilgisi öğretmeni adaylarının okuldaki rehberlik hizmetlerinin öğrencilere katkısına ilişkin metaforik algılarının incelenmesi). S. S. S. J., 4:18, 1859-1864. (2018)

22. Balcı, S. Okul psikolojik danışmanı öz yetkinlik ölçeği'nin Türk kültüründeki psikometrik özellikleri. Ahi Evran Ün. Kırşehir E. F. D. (KEFAD), 18:2, 633-649. (2017)

23. Erkan, S. İlköğretim öğrencilerinin rehberlik ihtiyaçlarının belirlenmesi üzerine bir araştırma. K. U.yg. Ĕg. Yön. 3:333-406. (1997)

24. Blustein, D.L. The Psychology of Working: A New Perspective for a New Era. In Blustein, D.L. (Eds) The Oxford Handbook of the Psychology of Working. International Debate Education Association. (2015)

25. Brown, S. D.\& Lent, R.W. Career development and counseling : Putting theory and research to work (2nd ed.). Canada: John Wiley \& Sons, Inc. (2013)

26. Gottfredson, L. S. Gottfredson's theory of circumscription, compromise, and selfcreation. In D. Brown (Ed.), Career choice and development (4th ed., pp. 85-148). San Francisco, CA: Jossey-Bass. (2002)

27. Gottfredson, L. S. Gottfredson's theory of circumscription, compromise, and selfcreation. In D. Brown \& Associate (Eds.), Career choice and development (4th ed., pp. 85-148). San Francisco, CA: Jossey-Bass. (2002)

28. Guichard, J., \& Lenz, J. Career theory from an international perspective. C. Dev. Qua., 54, 17-28. (2005)

29. Leung, S. A. The Big Five Career Theories. In Athanasou, J.A. \& Van Esbroeck, R. (Eds.) International Handbook of Career Guidance (pp. 115-132). Springer Science \& Business Media B.V. (2008) 
30. McMahon, M., \& Patton, M. (Eds.). Career counselling: Constructivist approaches. Abingdon, UK: Routledge. (2006)

31. Van Esbroeck, R. \& Athanasou, J.A. Introduction: An international handbook of career guidance. In Athanasou, J.A. \& Van Esbroeck, R. (Eds.) International Handbook of Career Guidance (pp. 1-22). Springer Science \& Business Media B.V. (2008)

32. Super, D. E. A life-span, life-space approach to career development. J. Vo. Beh.r, 16, 282-298. (1980)

33. Watts, T. Career education for young people: Rationale and provision in the UK and other European countries. In. J. Edu. Voc. G., 1, 209-222. (2001) 